\title{
Hubungan Stunting dengan Gangguan Kognitif pada Usia Remaja Awal di Kecamatan Jatinangor
}

Rafa Fathia Suhud, Eddy Fadlyana, Elsa Pudji Setiawati, Siti Aminah, Rodman Tarigan

Departemen Ilmu Kesehatan Anak Fakultas Kedokteran Universitas Padjadjaran/RSUP Dr. Hasan Sadikin, Bandung

Latar belakang. Stunting merupakan salah satu permasalahan kesehatan nasional maupun dunia. Diperkirakan stunting berhubungan dengan penurunan dalam tingkat kognitif, kapasitas belajar, motorik, dan fungsi bahasa.

Tujuan. Penelitian ini bertujuan menganalisis hubungan stunting dengan gangguan kognitif pada usia remaja awal di Kecamatan Jatinangor. Metode. Jenis penelitian ini merupakan studi penelitian analitik komparatif dengan metode potong lintang. Kriteria inklusi penelitian ini adalah murid sekolah dasar kelas 5-6 di Kecamatan Jatinangor. Kriteria eksklusi pada penelitian ini adalah pengambilan data yang tidak lengkap dan memiliki penyakit kronik. Pengambilan data berupa karakteristik subjek, antropometri dilakukan sesuai dengan prosedur WHO, dan fungsi kognitif menggunakan Mini Mental State Examination (MMSE) Folstein. Analisis data menggunakan Fisher's Exact Test.

Hasil. Penelitian ini terdiri dari 58 subjek yang terdiri dari 57\% perempuan dan 43\% laki-laki dengan rentang usia 10-12 tahun. Terdapat 26\% subjek yang termasuk kategori stunting dan 26\% yang termasuk kategori Mini Mental State Examination tidak normal. Berdasarkan hasil analisis bivariat menggunakan uji statistik Fisher's Exact Test didapatkan hubungan antara stunting dengan gangguan kognitif dengan nilai $\mathrm{p}=0,013$.

Kesimpulan. Dari hasil penelitian ini ditemukan terdapat hubungan bermakna antara stunting dengan gangguan kognitif pada usia remaja awal di Kecamatan Jatinangor. Sari Pediatri 2021;23(2):115-20

Kata kunci: gangguan kognitif, stunting, remaja awal

\section{The Relationship Between Stunting and Cognitive Impairment in Early Adolescence of Jatinangor Subdistrict}

Rafa Fathia Suhud, Eddy Fadlyana, Elsa Pudji Setiawati, Siti Aminah, Rodman Tarigan

Background. Stunting is one of the health problems encountered both nationally and internationally. It has been suspected that stunting correlates with a decrease in cognitive function, learning, motoric, and linguistic abilities.

Objective. The study aimed to analyze the relationship between stunting with cognitive impairment in early adolescence living in Jatinangor Subdistrict.

Methods. The research was conducted as a comparative analytical research using the cross-sectional study. The criteria for inclusion included primary school students in grade 5-6 who studies in Jatinangor Subdistrict. The exclusion criteria were incomplete data and those with chronic illnesses. The data obtained from the subjects were the characteristics, anthropometry in accordance with the WHO procedure, and the cognitive function assessed using the Mini Mental State Examination (MMSE). The data analysis was done using the Fisher's Exact Test. Result. The study included 58 subjects, which consisted of 57\% female and 43\% male, who were in the range of age 10-12 years old. Among the participants, $26 \%$ were categorized as stunting and 26\% were categorized as abnormal in the Mini Mental State Examination. Based on the bivariate statistical analysis using the Fisher's Exact Test, a significant relationship between stunting and cognitive impairment was found with a score of $\mathrm{p}=0.013$.

Conclusion. The results of this study showed a significant relationship between stunting and cognitive impairment in early adolescence of Jatinangor Subdistrict. Sari Pediatri 2021;23(2):115-20

Keywords: cognitive impairment, stunting, early adolescence

Alamat korespondensi: Rafa Fathia Suhud. Fakultas Kedokteran, Universitas Padjadjaran. Jalan Raya Bandung-Sumedang Km. 21 Jatinangor, Sumedang. Email: rafathias@gmail.com 
Rafa Fathia Suhud dkk: Hubungan stunting dengan gangguan kognitif pada usia remaja awal

$G$ izi merupakan hal yang penting dalam perkembangan dan pertumbuhan seorang individu. ${ }^{1}$ Indikator status gizi dapat didasarkan pada hasil pengukuran antropometri Tinggi Badan menurut Usia (TB/U) dan Indeks Massa Tubuh menurut Usia (IMT/U). ${ }^{2}$ Salah satu masalah dalam status gizi adalah stunting. ${ }^{3}$ Stunting merupakan kondisi anak usia 0-59 bulan dengan tinggi badan menurut umur berada di bawah -2SD dari standar median WHO. ${ }^{4} \mathrm{Hal}$ ini terjadi karena dampak kekurangan gizi kronis yang terjadi saat 1000 hari pertama kehidupan anak. ${ }^{2}$ Terdapat 144 juta anak di bawah lima tahun yang mengalami stunting di dunia. Lebih dari setengah populasi tersebut berasal dari Asia. ${ }^{5}$ Berdasarkan data riset kesehatan dasar (Riskesdas) tahun 2018, prevalensi anak di bawah lima tahun yang mengalami stunting di Indonesia sebesar 30,8\% dan untuk anak usia sekolah dasar (SD) 23,6\%. Di Jawa Barat, prevalensi stunting pada anak SD mencapai angka $22,8 \% .{ }^{6}$ Manifestasi klinis anak stunting berhubungan dengan penurunan dalam tingkat kognitif, kapasitas belajar, motorik, dan fungsi bahasa yang dapat menyebabkan pendapatan yang rendah di masa depan. ${ }^{7}$

Stunting dapat berdampak negatif dalam sistem kekebalan tubuh, pertumbuhan tidak memadai, perkembangan otak, dan perkembangan kognitif. ${ }^{8}$ Stunting yang terjadi saat usia dini sering dikaitkan dengan kemampuan kognitif yang rendah di akhir masa remaja. ${ }^{1}$ Dampak buruk akibat stunting dapat berlangsung seumur hidup dan dapat memengaruhi generasi selanjutnya. ${ }^{5} \mathrm{Hal}$ ini dapat menyebabkan beban jika tidak mendapatkan intervensi. ${ }^{7}$ Pada anak usia dini terjadi pertumbuhan otak yang cepat dengan proses mielinisasi, arborisasi dendritik, sinaptogenesis, dan pemangkasan sinaps. Hal tersebut ditandai dengan munculnya hampir seluruh fungsi sosial-emosional, perilaku dan kognitif.?

Kognitif merupakan seluruh kegiatan dan proses berpikir dari seseorang yang dibentuk melalui organisasi dan adaptasi. ${ }^{10}$ Kemampuan kognitif berkembang secara bertahap dengan perkembangan fisik dan sistem saraf pusat. ${ }^{11}$ Perkembangan kognitif memperlihatkan perkembangan bagaimana cara anak berpikir untuk menyelesaikan masalah yang dapat dipergunakan sebagai tolak ukur kecerdasan. ${ }^{12}$ Keadaan malnutrisi seperti stunting dapat menyebabkan perlambatan dalam proses mielinisasi, gangguan dalam neurotransmiter sinaps, dan produksi dendritik menurun. Hal tersebut dapat menyebabkan perkembangan kognitif mengalami perlambatan. ${ }^{13}$ Stunting yang terjadi di usia dini dapat memengaruhi kemampuan daya tangkap anak dalam mengikuti pelajaran dan dapat berpengaruh terhadap hasil prestasi belajar yang akan berdampak bagi masa depan. ${ }^{14}$

Kelompok anak usia sekolah mengalami perubahan baik secara fisik, kognitif, maupun psikososial. ${ }^{3}$ Periode remaja dimulai dari usia 10-12 tahun dan berakhir di usia 18-19 tahun. ${ }^{10}$ Pada periode remaja awal, terdapat perkembangan otak yang sangat pesat. ${ }^{15,16}$ Terdapat peningkatan plastisitas otak yang dapat memberikan individu memperoleh kemampuan dan kompetensi baru. ${ }^{16}$ Kemampuan dan kompetensi baru akan sulit untuk didapatkan secara maksimal jika terdapat gangguan dalam perkembangan individu tersebut.

Berdasarkan hal tersebut diperlukan suatu upaya untuk mengetahui hubungan stunting dengan gangguan kognitif pada anak kelompok usia remaja awal. Penilaian stunting dinilai berdasarkan Tinggi Badan menurut Usia $(\mathrm{TB} / \mathrm{U})$ yang dipetakan pada Z-Skor. Tes gangguan kognitif dilakukan menggunakan MiniMental State Examination (MMSE) folstein yang sudah diterjemahkan ke Bahasa Indonesia dengan sensitivitas $87 \%$ dan spesifisitas $82 \%$. Mini-Mental State Examination (MMSE) merupakan instrument yang dapat menjadi tes awal untuk menilai fungsi kognitif dalam populasi yang besar. ${ }^{3}$ Tes ini memerlukan waktu berkisar 5-10 menit. ${ }^{17}$

Berdasarkan data Dinas Kesehatan Jawa Barat tahun 2013, Kabupaten Sumedang termasuk ke dalam 9 kabupaten dengan prevalensi sangat pendek pada anak usia 5-12 tahun di atas prevalensi Jawa Barat yaitu sebesar $12,6 \%{ }^{18}$ Kecamatan Jatinangor merupakan salah satu dari 26 Kecamatan di Kabupaten Sumedang. ${ }^{19}$ Masih terbatas jumlah penelitian yang menganalisis hubungan stunting dengan gangguan kognitif pada usia remaja awal di Kecamatan Jatinangor. Berdasarkan hal itu, peneliti merasa perlu melakukan penelitian ini.

\section{Metode}

Penelitian ini merupakan penelitian analitik komparatif dengan metode potong lintang yang dilakukan pada 1 Januari 2019 hingga 30 Juni 2020. Penelitian ini menggunakan data primer yang diperoleh dari pengambilan data di SDN Cikeruh 2 dan SDN Mekarwangi di Kecamatan Jatinangor, Kabupaten 
Sumedang. Penentuan jumlah sampel menggunakan rumus analitik komparatif kategorik tidak berpasangan dengan total sejumlah 58 subjek. Dari beberapa sekolah di Jatinangor, terpilih dua sekolah yang didapatkan berdasarkan teknik pengambilan sampel dengan menggunakan metode clustered sampling dari seluruh subjek yang memenuhi kriteria inklusi serta tidak termasuk kriteria eksklusi. Kriteria inklusi pada penelitian ini adalah murid SD kelas 5-6 di Kecamatan Jatinangor dan orang tua mengisi informed consent. Adapun kriteria eksklusi pada penelitian ini adalah pengambilan data yang tidak lengkap dan memiliki penyakit kronik.

Variabel yang dinilai adalah stunting dan gangguan kognitif. Stunting ditentukan berdasarkan kriteria tinggi badan menurut umur yang dikategorikan menjadi pendek ( $<-2$ SD) dan normal $(\geq-2$ SD) berdasarkan standar WHO. ${ }^{20}$ Gangguan kognitif ditentukan berdasarkan kriteria yang dinilai menggunakan Mini-Mental State Examination (MMSE) Folstein dikategorikan menjadi normal (24-30) dan tidak normal (0-23). Tidak normal terdiri dari ringan (18-23) dan berat $(0-17) .^{3,21}$ Penilaian karakteristik subjek terdiri atas jenis kelamin (perempuan dan laki-laki) dan usia (10, 11, dan 12 tahun). Terdapat penilaian karakteristik pengukuran status gizi yang terdiri atas Indeks Massa Tubuh terhadap Umur (IMT/U) yang dikategorikan dalam sangat kurus, kurus, normal, gemuk, dan obesitas serta Tinggi Badan terhadap Umur (TB/U) yang dikategorikan dalam sangat pendek, pendek dan normal. ${ }^{20}$ Pengukuran antropometri tinggi badan dilakukan menurut prosedur WHO dengan berdiri tegak dilantai yang datar, membuka alas kaki, membuka perhiasan di kepala, dan posisi mata dan telinga paralel. Posisi belakang kepala, bahu, pantat, betis, dan tumit menyentuh dinding lalu tinggi badan diukur menggunakan microtoise. ${ }^{22}$ Instrumen penelitian ini menggunakan Mini-Mental State Examination Folstein yang sudah diterjemahkan ke dalam Bahasa Indonesia dan sudah divalidasi didapatkan dari penelitian Tarigan dkk. ${ }^{3,21}$ MMSE merupakan instrumen yang dapat digunakan sebagai tes penapisan untuk menilai kognitif dalam pemeriksaan neurologis rutin pada anak usia 4 tahun ke atas. ${ }^{3,17}$ Tes ini dapat digunakan sebagai tes awal dalam populasi besar dan memerlukan waktu yang singkat. ${ }^{3,23}$ Pengukuran antropometri dan wawancara MMSE dilakukan oleh tenaga terstandarisasi yang sudah terlatih. Data antropometri diolah dengan piranti lunak Anthroplus dari WHO dan kemudian data yang telah dikumpulkan dianalisis dengan menggunakan IBM SPSS Statistics. Untuk menganalisis hubungan digunakan uji statistik chi square dengan syarat tidak terdapat sel yang memiliki nilai expected $<5$ dan tidak terdapat nilai observed yang bernilai nol. Jika tidak memenuhi syarat uji chi square, maka akan menggunakan uji Fisher's Exact Test. Signifikansi uji chi square ditentukan berdasarkan nilai $\mathrm{p}<0,05$. Jika $\mathrm{p}<0,05$ maka terdapat hubungan signifikan, jika p $>0,05$ tidak terdapat hubungan yang signifikan.

Penelitian ini telah mendapatkan persetujuan etik dari Komite Etik Fakultas Kedokteran Universitas Padjadjaran dengan nomor 1452/UN6.KEP/EC/2019.

\section{Hasil}

Terdapat 58 subjek dalam penelitian ini. Pada Tabel 1 terdapat distribusi frekuensi karakteristik penelitian yang terdiri dari jenis kelamin, usia, IMT/U, TB/U, dan MMSE. Berdasarkan karakteristik subjek, mayoritas responden yang mengikuti penelitian ini berjenis

Tabel 1. Karakteristik subjek

\begin{tabular}{lc}
\hline Karakteristik & $\begin{array}{c}\text { Total N=58 } \\
\mathrm{n}(\%)\end{array}$ \\
\hline $\begin{array}{l}\text { Jenis kelamin } \\
\text { Perempuan }\end{array}$ & $33(57)$ \\
Laki-laki & $25(43)$ \\
Usia & \\
10 & $10(17)$ \\
11 & $33(57)$ \\
12 & $15(26)$ \\
IMT/U & \\
Sangat kurus & $3(5)$ \\
Kurus & $4(7)$ \\
Normal & $42(72)$ \\
Gemuk & $7(12)$ \\
Obesitas & $2(3)$ \\
TB/U & \\
Sangat pendek & $4(7)$ \\
Pendek & $11(19)$ \\
Normal & $43(74)$ \\
MMSE & \\
Normal & $43(74)$ \\
Ringan & $14(24)$ \\
Berat & $1(2)$ \\
\hline
\end{tabular}


Rafa Fathia Suhud dkk: Hubungan stunting dengan gangguan kognitif pada usia remaja awal

Tabel 2. Hubungan stunting dengan gangguan kognitif

\begin{tabular}{|c|c|c|c|c|}
\hline \multirow[b]{2}{*}{$\mathrm{TB} / \mathrm{U}$} & \multicolumn{2}{|c|}{ Gangguan kognitif } & \multirow[b]{2}{*}{$\begin{array}{l}\text { Total } \\
(\mathrm{n}=58)\end{array}$} & \multirow[b]{2}{*}{$\mathrm{p}$} \\
\hline & $\begin{array}{c}\text { Normal } \\
\mathrm{n}(\%)\end{array}$ & $\begin{array}{c}\text { Tidak Normal } \\
\mathrm{n}(\%)\end{array}$ & & \\
\hline Normal & $36(84)$ & $7(16)$ & $43(74)$ & \\
\hline Pendek & $7(47)$ & $8(53)$ & $15(26)$ & 0,013 \\
\hline Total & $43(74)$ & $15(26)$ & $58(100)$ & \\
\hline
\end{tabular}

kelamin perempuan dan berusia 11 tahun. Persentase jenis kelamin perempuan 57\%, sedangkan laki-laki $43 \%$. Urutan usia dengan persentase paling besar yaitu 11 tahun (57\%), 12 tahun (26\%) dan 10 tahun (17\%).

Berdasarkan karakteristik status gizi berdasarkan IMT/U didapatkan sangat kurus (5\%), kurus (7\%), normal $(72 \%)$, gemuk (12\%) dan obesitas (3\%). Kategori mayoritas subjek dalam karakteristik ini adalah normal (72\%). Dalam karakteristik status gizi $\mathrm{TB} / \mathrm{U}$ terlihat terdapat subjek yang termasuk kategori stunting yaitu sangat pendek (7\%) dan pendek (19\%). Mayoritas subjek dalam kelompok ini masih dalam kategori normal (74\%). Karakteristik gangguan kognitif dikategorikan berdasarkan hasil wawancara MMSE. Terdapat $74 \%$ yang termasuk kategori normal dan $26 \%$ yang termasuk kategori tidak normal. Kategori tidak normal terdiri dari ringan (24\%) dan berat (2\%).

Pada Tabel 2 terdapat analisis bivariat yang memperlihatkan hubungan stunting dengan gangguan kognitif. Karena terdapat nilai expected count $<5$ maka digunakan uji Fisher's Exact Test. Nilai Fisher's Exact Test yang didapatkan berdasarkan analisis tersebut $\mathrm{P}=0,013$. $\mathrm{Hal}$ ini menandakan terdapat hubungan signifikan antara stunting dengan gangguan kognitif $(\mathrm{P}<0,05)$.

\section{Pembahasan}

Penelitian ini bertujuan untuk menganalisis hubungan stunting dengan gangguan kognitif pada usia remaja awal di Kecamatan Jatinangor, Kabupaten Sumedang, Jawa Barat. Penelitian diikuti oleh 58 subjek yang merupakan siswa kelas 5 dan 6 SDN Cikeruh 2 dan SDN Mekarwangi. Mayoritas subjek penelitian ini perempuan dan berusia 11 tahun.

Terdapat 26\% subjek yang termasuk dalam kategori stunting, lebih besar dari data Riskesdas 2018 pada anak usia sekolah dasar di Indonesia $(23,6 \%)$ dan di
Jawa Barat $(22,8 \%) .{ }^{6}$ Determinan kejadian stunting dalam penelitian Picauly $\mathrm{dkk}^{14}$ yaitu pola asuh ibu, pengetahuan gizi ibu, pendidikan ibu, pendapatan keluarga, riwayat infeksi penyakit, asupan protein, dan riwayat imunisasi. Terdapat 2512 keluarga yang masih termasuk keluarga pra sejahtera di Kecamatan Jatinangor. ${ }^{24}$ Dari segi pendidikan, terdapat $44,15 \%$ penduduk berumur 15 tahun ke atas menurut karakteristik dan ijazah tertinggi yang dimiliki di Kabupaten Sumedang yang memiliki ijazah tertinggi Sekolah Dasar (SD) / Sederajat. ${ }^{25} \mathrm{Hal}$ ini dapat menjadi salah satu faktor penentu kejadian stunting di Kecamatan Jatinangor. Angka kejadian stunting yang tinggi masih menjadi masalah utama kesehatan masyarakat utama di negara berkembang. ${ }^{26}$ Stunting juga dapat dipengaruhi oleh interaksi kompleks yang saling memengaruhi antara faktor sosial dan komunitas seperti urbanisasi, ekonomi politik, sosiokultural, kepadatan populasi, serta akses ke layanan kesehatan dan pendidikan. ${ }^{7,27}$

Anak yang mengalami stunting sejak 2 tahun pertama kehidupan berisiko lebih besar mengalami kesehatan yang buruk dan pada usia dewasa dapat memengaruhi kondisi sosioekonominya. ${ }^{7}$

Pada penelitian kohort yang dilakukan oleh Sasongko $\mathrm{dkk}^{28} \mathrm{di}$ daerah perdesaan Tanjungsari, berat lahir, pendidikan ibu, sumber air minum, tipe kamar kecil, dan Tinggi menurut Usia (TB/U) saat usia 2 tahun merupakan prediktor stunting di usia remaja. Stunting saat usia dini masih dapat dikejar pertumbuhannya pada saat usia 2 hingga 5 tahun. Namun, pada penelitian Casale $^{29}$, anak yang telah pulih pertumbuhannya dari stunting akan tetap mendapatkan hasil tes kognitif yang rendah saat usia 5 tahun.

Dalam penelitian ini terdapat 26\% subjek yang termasuk dalam kategori Mini-Mental State Examination (MMSE) tidak normal (ringan dan berat). Persentase ini mendekati angka dalam penelitian oleh Tarigan $\mathrm{dkk}^{3}$ di Kabupaten Pangandaran, yaitu sebesar 27,8\%. Hal 
ini perlu mendapatkan perhatian karena berdampak dalam jangka pendek dan panjang untuk perkembangan pencapaian akademik, fisik, dan kesehatan mental anak. ${ }^{30}$ Tes MMSE masih merupakan tes awal untuk mendeteksi gangguan kognitif dengan sensitivitas 87\% dan spesifisitas $82 \%$. Perlu dilakukan penilaian lanjutan sebagai pemeriksaan standar fungsi kognitif. ${ }^{3}$

Hasil penelitian ini memperlihatkan hubungan bermakna antara stunting dengan gangguan kognitif. Hal ini sejalan dengan penelitian oleh Arafah $\mathrm{dkk}^{31}$ yang dilakukan di sekolah dasar di Sumatera Utara. Arafah dkk melaporkan hubungan bermakna antara stunting dengan kemampuan kognitif. Hal serupa juga diperlihatkan oleh penelitian Woldehanna $\mathrm{dkk}^{32}$ yang melaporkan bahwa stunting saat usia dini secara signifikan berhubungan negatif dengan kinerja kognitif anak. Picauly $\mathrm{dkk}^{14}$ melaporkan dampak yang sangat bermakna stunting terhadap prestasi belajar anak. Dalam penelitian tersebut dilaporkan akan terjadi penurunan prestasi belajar sebesar 0,444 setiap penurunan TB/U anak sebesar $1 \mathrm{SD}$. Keadaan stunting dapat berpengaruh terhadap prestasi belajar dengan memengaruhi kemampuan daya tangkap dalam mengikuti pelajaran di sekolah. Gashu ${ }^{33}$ melaporkan bahwa anak yang mengalami stunting dari dampak kekurangan beberapa makronutrien dan mikronutrien memiliki nilai kognitif yang lebih rendah dari seluruh tes psikologis. Crookston $\mathrm{dkk}^{34}$ membandingkan anak stunting dengan anak yang tidak pernah mengalami stunting, anak yang mengalami stunting cenderung memiliki usia lebih tua dibandingkan dengan usia anak pada kelas yang sama dan memiliki prestasi akademik yang lebih rendah.

Penelitian ini memiliki beberapa keterbatasan, yaitu menggunakan metode cross-sectional dan tidak dilakukan penelitian lebih lanjut di beberapa faktor yang dapat memengaruhi gangguan kognitif. Perlu dilakukan penelitian lanjutan dengan metode longitudinal untuk mengetahui riwayat pertumbuhan karena stunting terjadi akibat dampak kekurangan gizi kronis saat 1.000 hari pertama kehidupan anak. ${ }^{2}$ Faktor lain yang dapat memengaruhi gangguan kognitif yaitu faktor psikososial, ekonomi, pendidikan orang tua, dan interaksi ibuanak tidak diteliti. ${ }^{35,36}$ Kebaruan dalam penelitian ini ditemukan adanya persentase yang lebih tinggi dari rerata Indonesia dan Jawa Barat pada anak usia remaja awal yang termasuk kategori stunting di Kecamatan Jatinangor. Selain itu didapatkan hubungan signifikan antara stunting dengan gangguan kognitif khususnya pada usia remaja awal di Kecamatan Jatinangor.
Subjek yang termasuk dalam kategori stunting dan terdapat risiko gangguan kognitif perlu mendapatkan penanganan lanjutan di fasilitas kesehatan. Hal ini dapat dilakukan dengan melakukan intervensi dan edukasi mengenai pertumbuhan anak, stunting, dan gangguan kognitif agar terjadi peningkatan kualitas kesehatan pada remaja terutama di Kecamatan Jatinangor.

\section{Kesimpulan}

Terdapat 26\% subjek yang termasuk kategori stunting dan 26\% yang termasuk kategori MMSE tidak normal. Berdasarkan hasil uji Fisher's Exact Test terdapat hubungan bermakna antara stunting dengan gangguan kognitif pada usia remaja awal $(p=0,013)$.

\section{Daftar pustaka}

1. Solihin RDM, Anwar F, Sukandar D. Kaitan antara status gizi, perkembangan kognitif, dan perkembangan motorik pada anak usia prasekolah. Penelit Gizi dan Makanan 2013;36:62-72.

2. Trihono, Atmarita, Tjandrarini DH, dkk. Pendek (stunting) di Indonesia, masalah dan solusinya. Sudomo M, editor. Jakarta: Lembaga Penerbit Balitbangkes; 2015.

3. Tarigan R, Dhamayanti M, Fadlyana, Kusnandi Rusmil E. Different result of cognitive impairment screening in adolescent aged 10-12 Years with normal and in Pangandaran District. Am J Clin Med Res 2017;5:26-30.

4. Kementerian Kesehatan RI. Buletin stunting. Jakarta: Kementeri Kesehat Republik Indones; 2018.

5. UNICEF, WHO, World Bank. Levels and trends in child malnutrition: Key findings of the 2020 edition of the joint child malnutrition estimates. Geneva: WHO 2020;24:1-16.

6. Kementerian Kesehatan Republik Indonesia. Laporan Nasional Riskesdas 2018. Badan Penelit dan Pengemb Kesehat Dep Kesehat Republik Indones. 2018;

7. Prendergast AJ, Humphrey JH. The stunting syndrome in developing countries. Paediatr Int Child Health 2014;34:250-65.

8. Putri R, Nuzuliana R, Kurniawati HF. Management of stunting to improved children nutritional status and cognitive. 1st Int Respati Heal Conf 2019;490-500.

9. Deoni S, Dean D, Joelson S, Schneider N. Early nutrition influences developmental myelination and cognition in infants and young children. HHS Pub Access 2018;649-59.

10. Santrock JW. Child development. Edisi ke-13. New York: McGraw-Hill; 2011.

11. Diane P, Olds SW, Feldman RD. Human development. Edisi ke-10. Jakarta: Salemba Humanika; 2008.

12. Fithria, Alam TS. Status nutrisi dan perkembangan kognitif anak usia sekolah di Kecamatan Kuta Baro Aceh Besar. Idea Nurs J 2013;IV:35-44. 
13. Serly, Aminah S, Gamayani U, Rusmil K. Faktor-faktor antropometri yang berpengaruh terhadap fungsi kognitif dengan pemeriksaan MMSE dan subtes MMSE pada anak usia 10-12 tahun. Neurona 2013;30.

14. Picauly I, Sarci D, Toy M. Analisis determinan dan pengaruh stunting terhadap prestasi belajar anak sekolah di Kupang dan Sumba Timur, NTT. J Gizi dan Pangan 2013;8:55-62.

15. Kliegman RM, Stanton BF, III JWSG, Schor NF, Berhman RE. Nelson textbook of pediatics. Edisi ke-20. Berhman RE, penyunting. Philadelphia: Elsevier Inc.; 2016.

16. Bidzan-Bluma I, Lipowska M. Physical activity and cognitive functioning of children: A systematic review. Int J Environ Res Public Health 2018;15:800.

17. Ouvrier RA, Goldsmith RF, Ouvrier S, Williams IC. The value of the mini-mental state examination in childhood: A preliminary study. J Child Neurol 1993;8:145-8.

18. Dinas Kesehatan Provinsi Jawa Barat. Profil Kesehatan Provinsi Jawa Barat 2017. Bandung : Dinkes Jawa Barat; 2017.

19. Badan Pusat Statistik Kabupaten Sumedang. Kabupaten Sumedang dalam angka 2020. BPS Kabupaten Sumedang, penyunting. Sumedang: BPS Kabupaten Sumedang; 2020.

20. Kementerian Kesehatan Republik Indonesia. Hasil Pemantauan Status Gizi (Psg) Tahun 2017. Jakarta: Direktorat Gizi Masyarakat. Kemkes RI; 2017.

21. Folstein MF, Folstein SE, McHugh PR. Mini-mental state. A grading the cognitive state of patiens for the clinician. J Psychiatr Res 1975;12:189-98.

22. WHO. Training course on child growth assessment. World Health Organization. Geneva; 2008.

23. Khalida E, Fadlyana E, Somasetia H. Hubungan kebiasaan sarapan dengan prestasi belajar dan fungsi kognitif pada anak sekolah dasar. Sari Pediatri 2015;17:89-94.

24. Badan Pusat Statistik Kabupaten Sumedang. Kecamatan Jatinangor dalam angka 2019. Badan Pusat Statistik Kabupaten Sumedang; 2019.

25. Badan Pusat Statistik Kabupaten Sumedang. Statistik Kesejahteraan Rakyat Kabupaten Sumedang 2019. Badan Pusat Statistik Kabupaten Sumedang, penyunting. Sumedang: Badan Pusat Statistik Kabupaten Sumedang; 2019.
26. De Onis M, Blössner M, Borghi E. Prevalence and trends of stunting among pre-school children, 1990-2020. Pub Health Nutr 2012;15:142-8.

27. WHO. Childhood stunting: Context, causes and consequences WHO Conceptual Framework. WHO 2013;9:27-45.

28. Sasongko EPS, Ariyanto EF, Indraswari N, Rachmi CN, Alisjahbana A. Determinants of adolescent shortness in Tanjungsari, West Java, Indonesia. Asia Pac J Clin Nutr 2019;28:S43-50.

29. Casale D, Desmond C. Recovery from stunting and cognitive outcomes in young children: Evidence from the South African birth to twenty cohort study. J Dev Orig Health Dis 2015;7:163-71.

30. Satriawan E, Maika A, Mittinty MN, Lynch JW, Brinkman $S$, Harper S. Changes in socioeconomic inequality in Indonesian children's cognitive function from 2000 to 2007: A decomposition analysis. PLoS One 2013;8:e78809.

31. Arafah N, Lubis M, Fujiati II. Stunting and anemia are associated with cognitive abilities in primary school children. Glob J Res Anal 2019;8:16-8.

32. Woldehanna T, Behrman JR, Araya MW. The effect of early childhood stunting on children's cognitive achievements: Evidence from young lives Ethiopia. HHS Pub Access 2017;31:75-84.

33. Gashu D, Stoecker BJ, Bougma K, Adish A, Haki GD, Marquis GS. Stunting, selenium deficiency and anemia are associated with poor cognitive performance in preschool children from rural Ethiopia. Nutr J 2016;15:1-8.

34. Crookston BT, Schott W, Cueto S, dkk. Postinfancy growth, schooling, and cognitive achievement: Young lives. Am J Clin Nutr 2013;98:1555-63.

35. Warsito O, Khomsan A, Hernawati N, Anwar F. Relationship between nutritional status, psychosocial stimulation, and cognitive development in preschool children in Indonesia. J Nanomater 2012;2012:451-7.

36. Ford N, and Stein A. Risk factors affecting child cognitive development: A summary of nutrition, environment, and maternal-child interaction indicators for Sub-Saharan Africa HHS Pub Access 2017;7:197-217. 